\title{
Geoecological Assessment of the State of Soils in Functional Zones of the Territory of the Eastern Administrative Okrug of Moscow, the Russian Federation
}

\author{
S. V. Dubrova ${ }^{1, *}$, I. I. Podlipskiy ${ }^{1}$, P. S. Zelenkovskiy ${ }^{2}$, P. I. Egorov ${ }^{1}$, and E. M. Nesterov ${ }^{1}$ \\ ${ }^{1}$ The Herzen State Pedagogical University of Russia, 48, Moika Emb., St. Petersburg, Russia, 191186 \\ ${ }^{2}$ Saint Petersburg State University, 7/913B Universitetskaya Emb., St. Petersburg, Russia, 199034
}

\begin{abstract}
With the development of megalopolises, constant expansion of their borders and chaotic and - to a greater extent - unreasonable territorial division of lands, potential recreational areas are experiencing colossal anthropogenic load and can be found in the state of oppression, gradually moving into an industrial functional zone, from the environmental point of view. For the preservation of ecosystems and rational planning of urban development, it is necessary to pay special attention to the functional purpose and mode of use of the sites, which are the essence of zoning and governance in the field of urban development of land. This paper presents a geoecological assessment of the dynamics of changes in pollution halos among the functional areas of the Eastern Administrative Okrug of Moscow over the past 30 years. Geochemical series of pollutants were compiled with the help of methods of preliminary preparation and statistical data processing. A forecast of the spread of pollution in the surface horizon for the next 100 years is presented, taking into account the hydrogeological features of the territory of the Eastern Administrative Okrug of Moscow.
\end{abstract}

\section{Introduction}

In the context of this work, functional zoning means the allocation of sites that are relatively homogeneous in terms of natural features and man-made burden in order to develop further measures for their optimization and rational management and use (requirements for compactness and connectivity do not apply to the functional area). Subtle differentiation of functions is necessary for justifying calculations necessary to solve the problems of an integrated urban planning assessment, since various functions interact differently with the territory, with elements of engineering and transport infrastructure and with each other in terms of higher construction costs, risks, environmental damage, communication and social relations, etc.

\footnotetext{
* Corresponding author: dubrova.stanislav@gmail.com
} 
Identification of areas differing in the density of man-made burden and its functional orientation is the basis for predicting the ecological state of soils and grounds (Kosinova et al., 2002). Functional geoecological zoning, in addition, is the most important tool for managing the territory and resources of a megalopolis, which makes it possible to establish an optimal ratio of use and/or protection measures for a particular area, that is, a functional area is the main unit of territorial governance of a city [1].

When modeling the migration flows of pollutants among the functional areas of megalopolises, not only causal relationships should be considered, but also a universal academic basis for assessing and understanding the material migration in geoecological systems should be created, based on already accepted and understandable methods of engineering and environmental surveys and, most importantly, operating with a standard set of geochemical information. Thus, the practical application of the approach presented in the work can expand from a specific object of study to the framework of all the hypergenesis areas, depending on the required scaling. Preparation of an information model and its combination with the concept and methodology of functional zoning of territories, which is one of the most important stages in the development of a city master plan, predetermining its planning structure, will create a basis for the academic scientific direction on which all the subsequent developments will be based [2].

\section{Materials and methods}

The Eastern Administrative Okrug is one of 12 administrative areas in the City of Moscow, the Russian Federation. It includes 16 districts. It is the largest unit in terms of territory and it has the second largest population in the City of Moscow. It occupies 14.3\% of the city's territory.

In this work, in order to identify and characterize various types of "pure" man-made impact (of a certain direction, intensity and nature), the studied territories were divided into three groups, in accordance with the method of their use (functional zoning) [1]:

- industrial functional areas (sites) - territories and sanitary protection zones of industrial enterprises, territories and sanitary protection zones of man-made modified objects, transport infrastructure;

- residential functional areas (residential quarters) - areas of residential and public and business development. This area is transitional between industrial and recreational ones;

- recreational functional areas (parks) - background (reference) from the geochemical point of view of the territory within which green spaces are widespread. Designed for recreational purposes.

At the preparatory stage, a geoecological monitoring assessment of the chemical pollution of the studied areas, the Eastern Administrative Okrug of the City of Moscow, was carried out. This assessment is based solely on a standard set of materials for environmental engineering surveys in construction, but also it has a number of distinctive features of the preparation of information and its interpretation.

Geochemical data for monitoring the territory of the Eastern Administrative Okrug of Moscow over the past 30 years were compiled in the framework of monitoring programs of the Hygienic and Epidemiological Center in the City of Moscow Federal State-Funded Healthcare Institution - 1987, 1993 and 2009. The entire territory of the administrative unit covers an area of $154 \mathrm{~km}^{2}$ (Figure 1). In each of the above stated years, 230 samples of soils (urban soils) were taken from the depth of 0.0-0.2 m. Concentrations of chemical elements in soil and ground samples were determined in the laboratory by the atomic absorption spectrometry method (AAS) for heavy metals. 


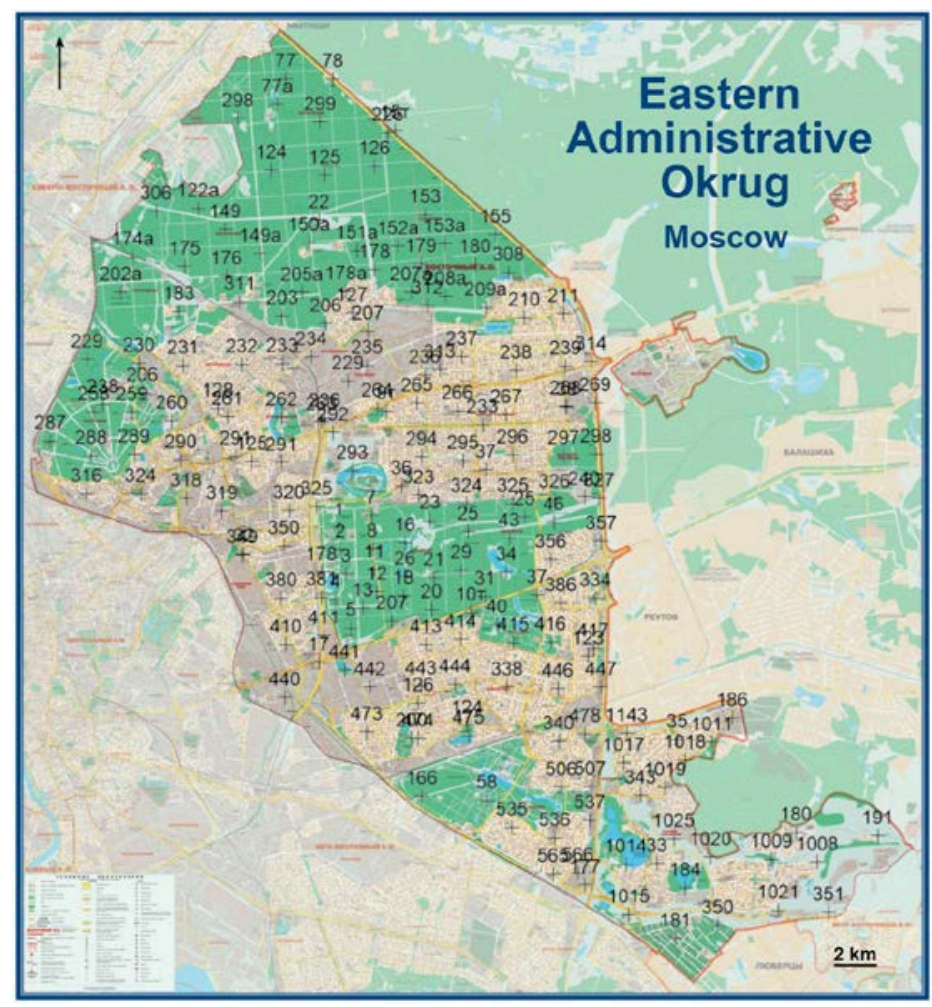

Fig. 1. Soil Sampling Points on the Territory of the Eastern Administrative Okrug, 2009.

Statistical assessment of the data was carried out using the Statistica 11, SPSS, Stadia software packages. Modeling of material migration flows in the near-surface horizon of urban soils and graphic interpretation of the results were carried out using the Processing Modflow 8.047, Surfer 12, Voxler 3, and Adobe Photoshop CS5 software packages.

In the context of this work, chemical pollution is taken as a change in the chemical composition of the abiotic component of the natural environment (soils and grounds) that has arisen under the direct or indirect impact of industrial, agricultural, household or other activities, causing a decrease in its quality. For the monitoring assessment of the ecological state of the studied areas, the contamination of soils and grounds was determined taking into account 32 heavy metals. For the purpose of better provision of main results, the work will present data processing only concerning 14 heavy metals of three hazard classes cadmium, mercury, beryllium, lead, zinc, cobalt, chromium, copper, molybdenum, nickel, vanadium, barium, tungsten, manganese.

The assessment of the danger of soil pollution by a complex of metals for the health of the population within this work was carried out according to the indicator of total pollution (Zct). According to the existing standards, with a total value of Zct less than 16, the soil belongs to the $1^{\text {st }}$ category of pollution (permissible), $16-32$ - to the $2^{\text {nd }}$ (moderately hazardous), $32-128$ - to the $3^{\text {rd }}$ (hazardous), more than 128 - to the $4^{\text {th }}$ category (extremely hazardous pollution) [3; 4].

\section{Results and Discussion}

In our studies, the territory of the Eastern Administrative Okrug of the City of Moscow is well suited for modeling the dynamics of changes in the total man-made burden on the 
components of the environment. The functional zoning of the Okrug's territory has not practically changed within its borders over the past 30 years and has remained constant, while the areas themselves, in relation to the urban development plan, have not actually migrated. This fact makes it possible to assess the migration (evolution) of the absolute component of man-made burden on the territory of the second largest administrative unit of the City of Moscow. Throughout the development of the Okrug, in the urban development plan, there is a close geochemical connection between the functional areas within the Okrug. It is impossible to exclude one functional area from another, the flow of man-made burden between the areas is traced every decade, while the local pollution of the industrial functional area is close to the average background of the adjacent residential areas, on which they have a direct impact (Figure 2, Figure 3, Figure 4).

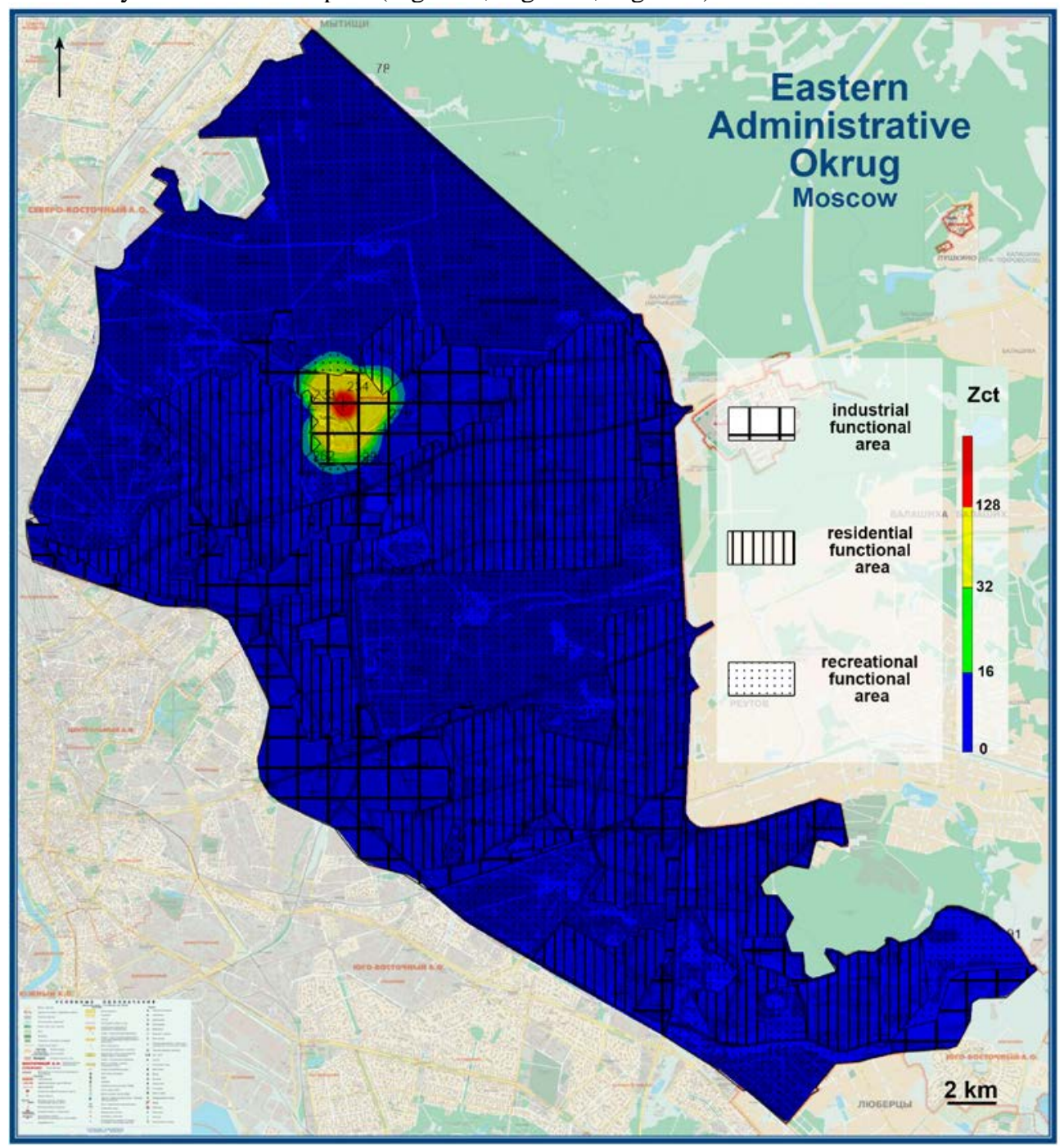

Fig. 2. Schematic Map of the Distribution of the Total Indicator of Soil Pollution, Taking into Account the Toxicity of Elements, the Eastern Administrative Okrug of the City of Moscow, 1987. 


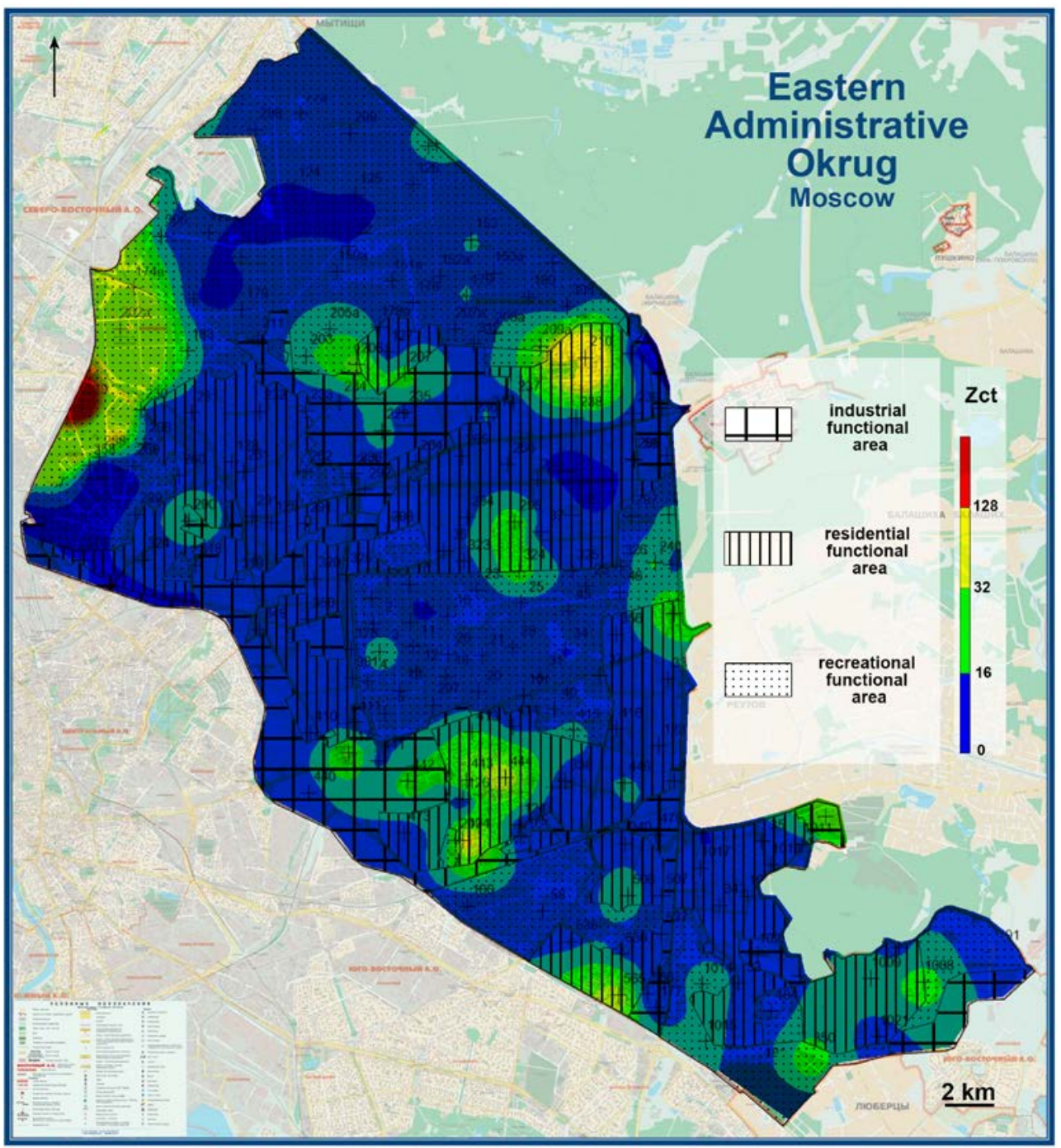

Fig. 3. Schematic Map of the Distribution of the Total Indicator of Soil Pollution, Taking into Account the Toxicity of Elements, the Eastern Administrative Okrug of the City of Moscow, 1993. 


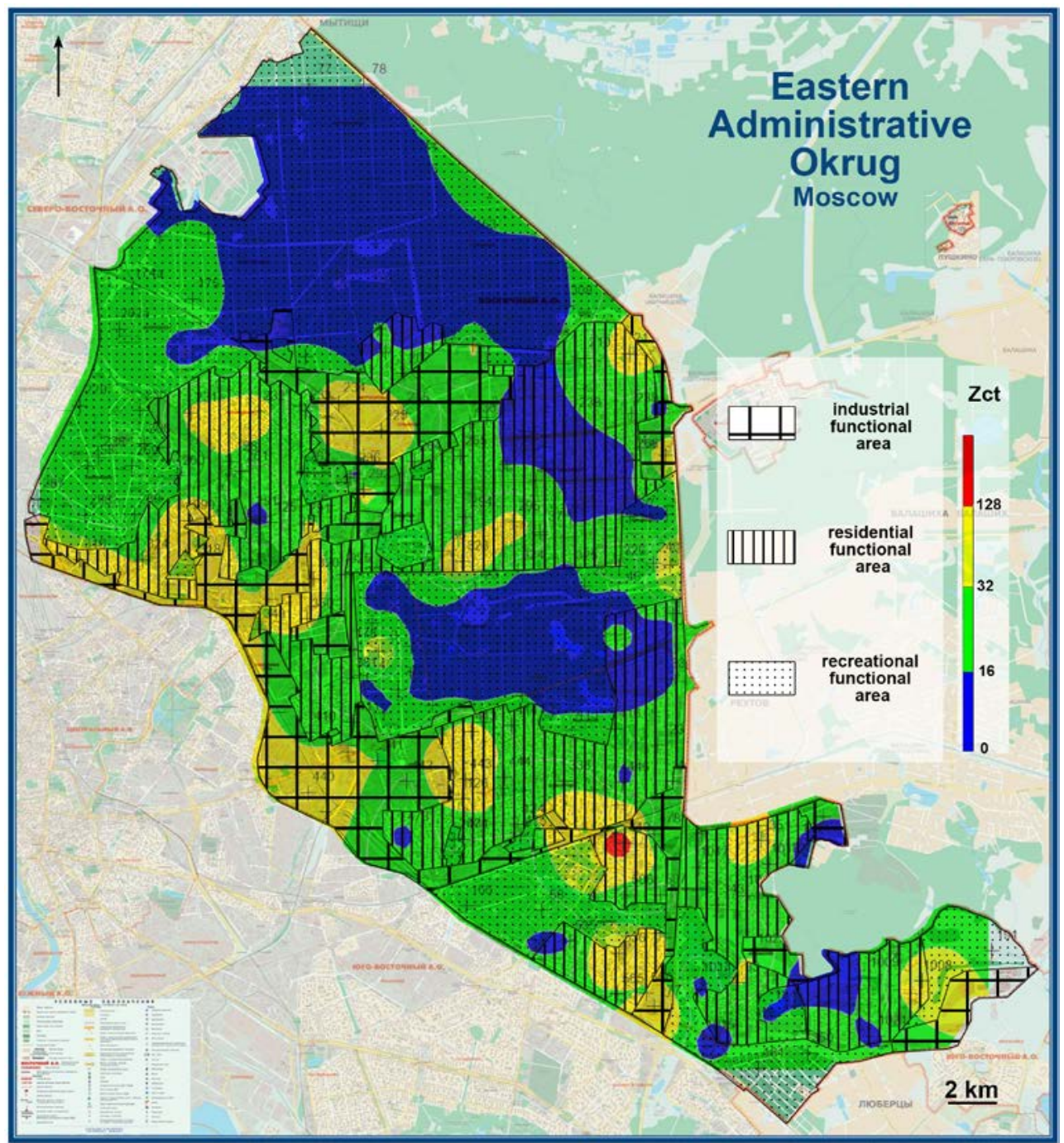

Fig. 4. Schematic Map of the Distribution of the Total Indicator of Soil Pollution, Taking into Account the Toxicity of Elements, the Eastern Administrative Okrug of the City of Moscow, 2009.

Table 1 shows data on the geochemical series (relative to the regional background) for all investigated functional zones of the megalopolis [5]. The data obtained and compiled in a certain way represent the use of a standard volume of geochemical information in the field of geo-ecology, through an in-depth analysis of which it becomes possible to expand the field of interpretation of the results $[6,7]$. In addition to stating the actual pollution within the framework of the geoecological assessment of soils, the research workers obtain a detailed portrait of each of the functional areas separately [8, 9, 10]. 
Table 1. Summary Table of the Geochemical Series of Heavy Metals of the Studied Objects of all Functional Areas

\begin{tabular}{|c|c|c|}
\hline Year & $\begin{array}{l}\text { Functional } \\
\text { area }\end{array}$ & Horizon 0.0-0.2 m \\
\hline \multirow{3}{*}{1987} & Industrial & $\begin{array}{c}\mathrm{Cd}>\mathrm{Pb}>\mathrm{Co}>\mathrm{Ba}>\mathrm{W}>\mathrm{Mo}>\mathrm{Cu}>\mathrm{Cr}>\mathrm{Ni}>\mathrm{Zn}>\mathrm{V}>\mathrm{Mn}> \\
\mathrm{Be}\end{array}$ \\
\hline & Residential & $\begin{array}{c}\mathrm{Co}>\mathrm{Cd}>\mathrm{Mo}>\mathrm{Be}>\mathrm{Pb}>\mathrm{Cu}>\mathrm{Cr}>\mathrm{Ni}>\mathrm{Ba}>\mathrm{W}>\mathrm{V}>\mathrm{Zn}> \\
\mathrm{Mn}\end{array}$ \\
\hline & Recreational & $\begin{array}{c}\mathrm{Co}>\mathrm{Cd}>\mathrm{Mo}>\mathrm{Be}>\mathrm{Pb}>\mathrm{Cu}>\mathrm{Cr}>\mathrm{Ni}>\mathrm{Ba}>\mathrm{W}>\mathrm{V}>\mathrm{Zn}> \\
\mathrm{Mn}\end{array}$ \\
\hline \multirow{3}{*}{1993} & Industrial & $\begin{array}{c}\mathrm{Cd}>\mathrm{Hg}>\mathrm{Mo}>\mathrm{Co}>\mathrm{Be}>\mathrm{Pb}>\mathrm{Cu}>\mathrm{Cr}>\mathrm{Ba}>\mathrm{V}>\mathrm{Ni}>\mathrm{W}> \\
\mathrm{Zn}>\mathrm{Mn}\end{array}$ \\
\hline & Residential & $\begin{array}{c}\mathrm{Co}>\mathrm{Ba}>\mathrm{Hg}>\mathrm{Cd}>\mathrm{Mo}>\mathrm{Pb}>\mathrm{Be}>\mathrm{W}>\mathrm{Ba}>\mathrm{Cu}>\mathrm{Cr}>\mathrm{Ni}> \\
\mathrm{Zn}>\mathrm{Mn}\end{array}$ \\
\hline & Recreational & $\begin{array}{c}\mathrm{Co}>\mathrm{Hg}>\mathrm{Cd}>\mathrm{Mo}>\mathrm{Ba}>\mathrm{Be}>\mathrm{W}>\mathrm{Pb}>\mathrm{Cu}>\mathrm{Cr}>\mathrm{Ni}>\mathrm{V}> \\
\mathrm{Mn}>\mathrm{Zn}\end{array}$ \\
\hline \multirow{3}{*}{2009} & Industrial & $\begin{array}{c}\mathrm{Zn}>\mathrm{Pb}>\mathrm{Cu}>\mathrm{Co}>\mathrm{Ni}>\mathrm{Be}>\mathrm{Cr}>\mathrm{Mo}>\mathrm{Cd}>\mathrm{Hg}>\mathrm{Ba}>\mathrm{V}> \\
\mathrm{W}>\mathrm{Mn}\end{array}$ \\
\hline & Residential & $\begin{array}{c}\mathrm{Zn}>\mathrm{Pb}>\mathrm{Cu}>\mathrm{Co}>\mathrm{Be}>\mathrm{Cd}>\mathrm{Ni}>\mathrm{Ba}>\mathrm{Mo}>\mathrm{Cr}>\mathrm{Hg}>\mathrm{V}> \\
\mathrm{W}>\mathrm{Mn}\end{array}$ \\
\hline & Recreational & $\begin{array}{c}\mathrm{Zn}>\mathrm{Pb}>\mathrm{Cu}>\mathrm{Co}>\mathrm{Ni}>\mathrm{Be}>\mathrm{Cr}>\mathrm{Mo}>\mathrm{Cd}>\mathrm{Hg}>\mathrm{Ba}>\mathrm{V}>\mathrm{W} \\
>\mathrm{Mn}\end{array}$ \\
\hline
\end{tabular}

In modeling, the migration of heavy metals was estimated relative to the local background concentrations of the recreational functional area and the average regional values. Thus, the assessment excluded atmospheric pollution, and within the framework of the model, only the man-made burden of the industrial area was estimated. The paper presents model data on the migration of marker elements in different horizons (Figure 5).

Descriptive statistics methods and detailed geochemical characteristics of the functional areas of the megalopolis characterized the spread of pollution from the area of increased pressure of man-made origin. Based on the results of the analysis, the initial geochemical "portraits" of the functional areas were compiled, the main indicator elements (markers) were identified, and the pollution assessment was carried out in relation to the existing norms adopted in the Environmental Law of the Russian Federation. Therewith, the basis was built for further assessment and forecast of the spread of pollution, within the framework of this work - "man-made burden", in the territory of conjugated functional areas. In the Processing Modflow 8.047 program, detailed hydrogeological models of industrial, residential and recreational functional areas of the administrative unit of the City of Moscow were built. The MT3DMS software package was used to simulate the migration in the surface soil horizon.

The area of hydrogeological modeling of the administrative unit of the City of Moscow made $117.6 \mathrm{~km}^{2}$. The modeling grid included more than 1,500 elementary cells $(500 * 500$ meters). The migration of pollutants was traced only in the surface horizon, represented mainly by calculous glaciofluvial sands with thin cover argil sand grounds, ancient alluvial glaciofluvial sands and sandy loams with interlayers of argil sand grounds, glaciolacustrine argil sand grounds with interlayers of sands and shallow-braced sand-loam deposits. 


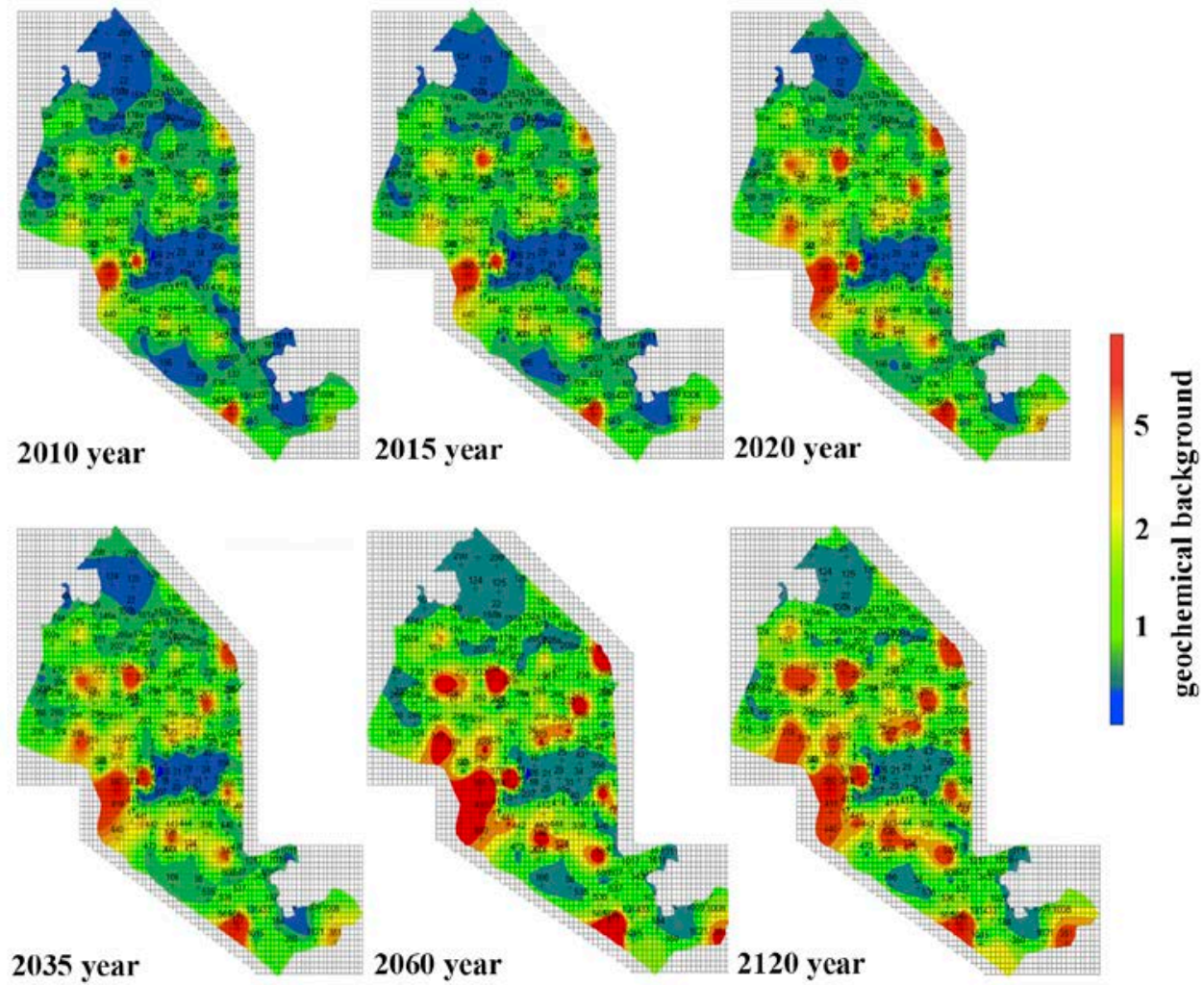

Fig. 5. Zinc Migration in the Surface Horizon 0.0-0.2 $\mathrm{m}$ in All Functional Areas of the Eastern Administrative Okrug of the City of Moscow.

Due to high concentrations of heavy metals used as markers in the industrial functional area, geochemical models for all analyzed pollutants showed fairly similar values. Obviously, differences in the migration of elements can be observed. They are mainly associated with differences in initial concentrations and, e.g., distribution coefficients in parent rocks. Notwithstanding, they will more likely refer to the types of geoecological objects in the territories of functional areas than to pollutants. The obtained models (for example, the migration of zinc in the surface horizon, Figure 5) of indicator elements can be considered sufficient for predicting the migration of pollution halos [11, 12].

In the 5-10 years forecast (relative to the research data) until nowadays, with a relative unchanged level of man-made burden, an increase in the pollution halo by 200-300 meters in the southeastern/eastern direction can be recorded. With a time span of more than 25 years, the increase makes 400-1,000 meters (Figure 3.5). Taking into account the dynamics of the increase in the man-made burden and the change in its genesis since 1987, it can be argued that the man-made impact will be more exposed to the territories of the residential area conjugated to the industrial functional area due to the lower potential of ecosystem auto-regeneration.

\section{Conclusions}

In this study, a comprehensive assessment of the current state of soils of various functional areas of the Eastern Administrative Okrug of the City of Moscow was performed and 
significant differences in the level and nature of man-made burden in each of them were highlighted. The prospects of zonal consideration of territories, that is, a new approach to thinking in the field of geo-ecology, were proved.

As part of the functional zoning of the city's territories, detailed geochemical series of pollutants and geochemical maps of the functional areas of the megalopolis were created. Taking into account the possibility of identifying the zoning of geochemical characteristics in the touchpoint of the lithosphere and the technosphere as a whole, the approach presented in this work for analyzing the processes of migration of matter is universal and is not tied to the scale characteristics of the objects under consideration. At the same time, operating with standard sets of methods for obtaining and volumes of information legally established and used nowadays in engineering and environmental surveys, increases significantly the availability and applicability of the integral approach to dividing the flow of the material migration through the functional areas of the megalopolis.

The methodological approach presented in this work can be used as a recommendation for cadastral survey. The methodology versatility and basicity makes it possible to compile small-scale maps of megalopolises and municipal areas as well as large-scale maps of individual groups of areas.

\section{References}

1. Dubrova S V, Podlipskiy I I, Kurilenko V V, Siabato W 2015 Environ Pollut 197 165172

2. Dubrova S V, German, V 2019 IOP Conf. Ser.: Mater. Sci. Eng 663 1-5

3. Vorenhout M, VanStraalen N M, Eijsackers H J P 2000 Environ Toxicol Chem 19 21612163

4. Maurya A, Kesharwani L, Mishra M K 2018 IJRASET 6(VI) 1188-1192

5. Bunemann E K, Bongiorno G, Bai Z, Creamer R E, De Deyn G, De Goede R, Fleskens L, Geissen V, Kuyper T W, Mäder P, Pulleman M, Sukkel W, van Groenigen J W, Brussaard L 2018 Soil Biol. Biochem. 120 105-125

6. Marzougui A, Mammou A, 2006 C R Geosci 338(16) 1176-1183

7. Podlipskiy I I 2015 Ecological and geological assessment of the territory of landfills for household waste (LAP Lambert Academic Publishing) p 200

8. F. De Laender, M. Morselli, H. Baveco, P.J. Van den Brink, A. Di Guardo 2015 Environ. Int. 74 181-190

9. Evstafieva E V, Bogdanova V M, Minkina T M Sushkova S N, Baranovsky N V, Manjieva S S, and Antonenko E M 2018 Tomsk Polytechnic University Bull. 329(10) $19-29$

10. Efremov I V, Gorshenina E L, Rakhimova N N, and Khismatullin Sh Sh 2015 Orenburg State University Bull. 10(185) 388-390

11. Dragan N A 1983 Soil of Crimea (Simferopol: SSU) p 95

12. Buzmakov S A, Kostarev S M 2009 Introduction to environmental monitoring (Perm: PSU) p 178 